\title{
Affirmative Action in India and the United States: the Untouchable and Black Experience
}

\section{by $M$. Varn Chandola*}

\section{INTRODUCTION}

To alleviate discriminatory practices against certain historically oppressed groups, a small number of countries have adopted affirmative action. In the United States, affirmative action is defined as a system of preferential treatment for minorities and women which attempts to compensate them for being denied opportunities of advancement due to past and present discrimination. ${ }^{1}$ Other countries, like India, have adopted affirmative action to deal with the disadvantaged segments of their populations. ${ }^{2}$ While it may surprise some scholars that countries other than the United States employ affirmative action, India utilized such preferential treatment well before the United States ${ }^{3}$. The United States developed affirmative action to fight discrimination against minority groups and women, while India created affirmative action to remedy its history of discrimination against groups, such as the "untouchables," who occupy the lowest rung in the Hindu caste system. Various names have been attributed to Indian affirmative action. For the purposes of this note, the term "compensatory discrimination," as used by such legal scholars as Parmanand Singh and Marc Galanter, will refer to India's affirmative action programs. ${ }^{4}$

The comparison between the United States and Indian affirmative action systems becomes even more interesting upon observing that blacks

- Private practitioner in Tucson, Arizona.

1. Laurence H. Tribe, American Constitutional Law $\$ \$ 16-22$, at 1523 (2d ed. 1988). Professor Tribe also indicates that one of the remedial goals of affirmative action is to create racial or gender diversity. Id.

2. Other countries, such as Japan and Israel, have also employed such forms of preferential treatment. Marc Galanter, Competing Equalities 562, n.15 (1984).

3. Id. at xvii.

4. Marc Galanter points out that the many names for affirmative action in India are similar to the different names used in the U.S. for affirmative action such as "reverse discrimination." Other names that describe India's affirmative action programs include "special treatment," "protective discrimination," "special provision," etc. Id. at 2-3. 
in the United States and untouchables in India share similar histories of discrimination. It is especially noteworthy that each country has influenced the development of the other's affirmative action programs. Given that the United States and India are so geographically distant from each other and share minimal cultural interaction, finding any similarities between the two countries seems reason enough for investigation.

Special emphasis will be given to U.S. and Indian affirmative action programs as they relate to black and untouchable experiences. In examining black and untouchable experiences, the discussion will attempt to reveal the similarities between the affirmative action programs in the United States and India, the influences one has had on the other, and the potential for future interaction. The primary focus will be on Indian influences and perceptions regarding the American affirmative action system and civil rights history.

\section{Systems of Discrimination}

The Hindu caste system is based on a social hierarchy which assigns untouchables to the lowest class. ${ }^{5}$ Traditionally, the caste system was divided into the following four classes, or Varnas, in order of rank: The Brahmins, or the priests and scholars; the Kshatriyas, or the kings and warriors; the Vaishyas, or the merchants and the business class; and the Shudras (who are today referred to as the "untouchables"), ${ }^{6}$ or the serfs and laborers. Within each class exist subgroups called "jatis," for which the correct English translation is "castes." Traditionally, the untouchable castes had been restricted to employment

5. Dandekar, Dharma, The First End Of Man, in Sources of Indian Tradition 224 (William T. de Bary ed., 1958).

6. Interview with Anoop C. Chandola, Professor of East Asian Studies at the University of Arizona, in Tucson (Jan. 18, 1991)(Professor Chandola is the author of The Way to True Worship: A Popular Story of Hinduism (1991)). Some scholars consider untouchables even below the traditional Shudra class. Id. From the traditional Hindu point of view, however, all untouchables are considered Shudras. See David R. Kinsley, Hinduism 123 (1982); Dandekar, supra note 5, at 224. Different names are ascribed to untouchables. The name used depends upon the context in which they are mentioned, i.e., in ancient religious texts they were known as "Shudra." Chandola, supra. The many names employed for untouchables are not unlike the many different names ascribed to blacks in the United States. (i.e., Negroes, Afro-Americans, and other such terms).

7. Chandola, supra note 6 . 
in menial labor and other occupations that were considered inferior by the higher caste members. ${ }^{8}$

The Hindu caste system is a hierarchy of endogamous and permanent groups regulated by complex social codes and sanctions, and various behavior patterns, such as diet, dress, custom and occupation. Traditionally, untouchables lived under a strict system of segregation that was rigidly enforced. 9 The penalties for breaking the rules of segregation were severe. ${ }^{10}$ Today, the caste system is not as rigidly adhered to since the Indian government has created a number of legal provisions giving untouchables greater rights. Article 17 of the Indian Constitution, adopted in 1949, two years after gaining independence from Great Britain, officially abolished the concept of untouchability. ${ }^{11}$

8. Id.

9. Untouchables had very little social mobility. Often they were restricted or denied access to schools, temples, wells, shops, eating places and other public facilities. They could not eat with or live near higher caste members. Galanter, supra note 2, at 15. These rules of segregation were supported by the rationale that because untouchables were considered a source of physical and spiritual pollution, they had to be kept at as far a distance away as possible. Edward Harper, Ritual Pollution as an Integrator of Caste and Religion, in ReLigion in South Asia (Edward Harper ed., 1964); Dandekar, supra note 5, at 224; KinsLEY, supra note 6, at 134-35. Certain interactions were deemed necessary for economic reasons. For example, higher caste members needed to establish various business contacts to secure the performance of services traditionally held by untouchables. KINSLEY, supra note 6, at 134 .

10. Chandola, supra note 6.

11. India Const. art. 17.

The British empire has often been given credit for introducing egalitarian ideals to India. It is true that British-educated Indians imbued with democratic ideals prompted the abolition of untouchability. Nevertheless, the fact that the British instituted their own system of caste-like discrimination which oppressed the Indians should not be overlooked. Francis G. Hutchins, The Illusion of Permanence ch. IV \& V (1967); Myron Weiner \& Mary F. Katzenstein, India's Preferential Policies 141 (1981). Furthermore, a number of movements espousing equality had arisen in India well before the British arrived there. Buddhism, for example, established in India (circa 500 B.C.) eschewed the caste system and notions of inequality. Mahendra P. Sharma, The Concept of Equaltry in the Indian Constitution 18-22 (1983); Weiner \& Katzenstein, supta, at 141. Various Hindu movements also emphasized the virtue of equality. Chandola, supra note 6. See also Sharma, supra at 18-22. The ancient egalitarian concepts of Vedanta and Bhakti were evolved to counteract the vama 'class' and jati 'caste' stratification. Chandola, supra note 6 . The Vedanta, meaning the end of the Veda or knowledge, was developed in the Upanishads which ended the Vedic period of Hindu society. Id. In that period (circa 1000 B.C.), a person was believed to be born in one of the four classes, and the class could not be changed. Id. The Vedanta philosophers, who were not necessarily priests or Brahmins by birth, believed that all were one Brahman, or absolute Self, in reality. Id. Brahman was considered to be 
Other Articles also gave untouchables various rights, ${ }^{12}$ and additional provisions which granted untouchables greater rights were soon added. ${ }^{13}$ Despite the Indian government's efforts to improve the status of untouchables, the social stigma of untouchability remains.

The United States has a comparable history of discrimination in its treatment of blacks. ${ }^{14}$ Slavery, like untouchability in India, was deeply rooted in American history. ${ }^{15}$

Discrimination against blacks in the form of Black Codes and Jim Crow laws existed in the post-Civil War era and these methods of discrimination continued well into the middle of the twentieth century. ${ }^{16}$ Black Codes prevented blacks from entering into occupations other than menial labor. ${ }^{17}$ Under Jim Crow laws, blacks lived in segregated neighborhoods and were denied or restricted in access to public facilities, such as schools, churches, restaurants, and transportation ${ }^{18}$. Like slavery, the Jim Crow system was supported by the assumption of innate white supremacy over blacks. ${ }^{19}$ The precedent for judicial support of Jim Crow laws was established in Plessy v. Ferguson, ${ }^{20}$ in which the United States Supreme Court held that there was neither a Thirteenth nor Fourteenth Amendment violation in maintaining separate facilities for blacks and whites. ${ }^{21}$ The Court observed that although blacks and whites were relegated to separate facilities, the races were nevertheless equal. ${ }^{22}$ The Court considered segregated facilities equal despite over-

indescribable, but was referred to with the neutral pronoun tat 'that, it'. Id. The acceptance of Brahman as existence invalidated distinctions of class and sex. Id. With this non-dualistic (advaita) philosophy was developed the dualistic (dvaita) practice of Bhatti 'devotion'. Id. In this practice there were only two distinctions: deity and devotee. Id. All devotees were equal in relation to the deity. Id.

12. See infra text accompanying notes $36-66$.

13. Id.

14. While some scholars have criticized past attempts to compare discrimination in India and the United States due to temporal and cultural differences, the discussion will focus on the similarities in restricted social mobility among blacks and untouchables rather than when or where such mistreatment took place.

15. See Geofreey Stone et al., Constitutional Law 435-37 (1986) [hereinafter SrONE].

16. See Stone, supra note 15 , at ch. $5 \& 10 ;$ C. Vann Woodward, The Strange Career of Jim Crow 144-147 (3d ed. 1974).

17. See Stone, supra note 15 , at 445 .

18. WOODWARD, supra note 16 , at 7 .

19. Id. at 11 .

20. 163 U.S. 537 (1896).

21. Id.

22. Id. 
whelming evidence of the inferior conditions of black facilities. ${ }^{23}$ In reality, blacks lacked access to many of the same public facilities as did the untouchables. The Jim Crow laws, in effect, discriminated against blacks in the same way that the caste system discriminated against the untouchables. ${ }^{24}$ Untouchables and blacks, despite differing cultural experiences, suffered from similar forms of suppression. Both groups bore a "badge of servitude." 25

\section{Similarity in Constitutional Safeguards for Blacks and UNTOUGHABLES}

India's constitution, enacted in 1947, created a number of safeguards for the untouchables, who are referred to under the constitutional nomenclature as the "Scheduled Castes." 26 The framers of the Indian Constitution sought methods that would alleviate the oppressed status of untouchables. ${ }^{27}$ The consensus was that without a system of compensatory discrimination or affirmative action, untouchables would be unable to successfully compete with the rest of society. ${ }^{28}$

The Indian Constitution, unlike the U.S. Constitution, expressly provides for affirmative action, or "compensatory discrimination." 29 No controversy, therefore, exists over the constitutional validity of affirmative action in India. The Indian Constitution also expressly allows

23. See WoOdWARd, supra note 16, at 144-47.

24. See Gunnar Myrdal, An American Dilemma: The Negro Problem and Modern Democracy 668 (1962); Gerald D. Berreman, Caste in India and the Uniled States, in CAste ANd Other InEquities 1-13 (Gerald Berreman ed., 1979) gives instances of the similar disabilities which blacks and untouchables faced.

25. Plessy v. Ferguson, 163 U.S. 537, 562 (1896).

26. George H. Gadbois, Affimative Action in India: The Judiciary and Social Change, 8 Law \& Policy 329, 330 (1986). Regarding differing terminology for untouchables, see supra note 6 . Members of the scheduled caste are generally considered by the public as being untouchables. The British first used the term "Scheduled Caste" in 1935 when they were in the process of creating a schedule which listed the lowest Hindu castes. The list was made with the purpose of determining which groups were entitled to certain constitutional safeguards. Id. The President, under Article 341, has the power to designate the communities that belong within the Scheduled Castes category.

27. Parmanand Singh, Equality, Reservation and Discrimination in India 20-21 (1982).

28. Id.

29. Stephen L. Wasby, "Compensatory Discrimination" and American "Affirmative Action": Some Parallels - A Review of Galanter's Competing Equalities, 8 LAW \& PoL'y 379,380 (1986). 
"reservations" or quotas. ${ }^{30}$ In the United States, in contrast, the Fourteenth Amendment has been interpreted to permit affirmative action. ${ }^{31}$ Furthermore, the constitutional validity of quotas in the United States remains unclear. ${ }^{32}$ When discussing affirmative action in both countries, it is important to note that such programs include other groups besides blacks and untouchables. Just as affirmative action programs in the United States encompass minorities, such as Hispanics and Native Americans, the Indian Constitution also includes other groups, such as the "Scheduled Tribes" (ST) ${ }^{33}$ and "Other Backward Classes" (OBC). ${ }^{34}$ The Scheduled Castes (SC), Scheduled Tribes, and Other Backward Classes are collectively referred to as the "backward classes" under the Indian Constitution. ${ }^{35}$

\section{A. Constitutional Safeguards for the Scheduled Castes}

The safeguards contained in the Fundamental Rights ${ }^{36}$ section of the Indian Constitution closely resemble affirmative action programs in the United States. ${ }^{37}$

Article 14 of the Indian Constitution establishes the general right of equality:

The State shall not deny to any person equality before the law or the equal protection of the laws within the territory of India. ${ }^{38}$

30. Singh, supra note 27 , at 66-67.

31. John Nowak \& Ronald Rotunda, Constitutional Law 655-98 (1991).

32. TRIBE, supra note 1 , at 1531 .

33. These are basically the tribal or "aboriginal" (as the British used the term) people of India who lived apart from mainstream Hindu society. See Alan M. Katz, Benign Preferences: An Indian Decision and the Bakke Case, 25 Ам. J. Сомp. L. 611; Galanter, supra note 2, at 147; Singh, supra note 27, at 111 . The President has the power to designate the Scheduled Tribes. See India Const. art. 342.

34. The Other Backward Classes (OBC) is a legislatively designated category consisting of many different groups who are defined as socially and economically "backward". These groups, while they tend to come from groups which are higher than the untouchables, have allegedly suffered from serious disabilities. See Galanter, supra note 2, ch. 6 , which gives an excellent discussion of the status of the OBC. Gadbois points out that since most groups are eligible for the $O B C$ designation, the right to be included in this category is often subject to political maneuvering. For instance, politicians will often lobby for a certain group to be classified under the OBC category for the sake of gaining popularity and critical votes from such groups. Gadbois, supra note 26 , at 332 . Thus, politics often impede the designation of truly deserving groups under the $\mathrm{OBC}$ category.

35. Galanter, supra note 2, at 3 .

36. Articles 12 through 35 constitute the Fundamental Rights.

37. For parallels, see Marc Galanter Symposium articles in 8 LAW \& PoL'y 323-87.

38. India, like the United States, has a federal government in which power is 
The Article 14 concept of equality espouses the principle that similarly situated persons will be treated alike. ${ }^{39}$ The law, therefore, need not apply identically to each and every person. ${ }^{40}$ Durga Das Basu, a renowned Indian constitutional law scholar, sums up the concept of equality as follows:

The principle of equality does not mean that every law must have universal application for all persons who are not by nature, attainment or circumstances in the same position, as the varying needs of different classes of persons often require separate treatment. ${ }^{41}$

Some degree of inequality exists in any classification. ${ }^{42}$ The state, however, may only create "reasonable classification[s]." "43 In Akhil Bharatiya Soshit Karmachari Sangh $v$. Union of India, ${ }^{44}$ for example, the Indian Supreme Court held that a reservation (quota) for the Scheduled Castes and Tribes which was not substantially above fifty percent was a reasonable classification. ${ }^{45}$ The Court stated, however, that arbitrary and unreasonable classifications were unconstitutional. ${ }^{46}$

Article 14's interpretation of "equality" provides the theoretical basis for giving preferential treatment to the Scheduled Castes under the "reasonable classification" standard. ${ }^{47}$ Moreover, the Indian Constitution leaves little room to challenge the legitimacy of preferential treatment as specific articles give the state the power to implement affirmative action programs. Article $16(4)$ states:

Nothing in this article shall prevent the State from making any provision for the reservation of appointments or posts in

shared between the central government and the states. See India Const. art. 12. The prohibition against discrimination by the "state" implies that both the federal and state governments are bound by Article 14. Durga Das Basu, Shorter Constitution OF INDIA 12-14 (9th ed. 1984).

39. Basu, supra note 38 , at 25 (citing Chiranjit Lal v. Union of India, A.I.R. 1951 S.C. 41).

40. Id.

41. Id.

42. Id.

43. Id. at 26 (citing Budhan v. State of Bihar, A.I.R. 1955 S.C. 191; Balaji v. State of Mysore, A.I.R. 1963 S.C. 649).

44. A.I.R 1981 S.C. 298.

45. Id.

46. BAsu, supra note 38 , at 25 (citing Ramana v. I.A.A, A.I.R. 1976 S.C. 1628 (para. 11); Kasturi v. State of Jammu and Kashmir, A.I.R. 1980 S.C. 1992 (para. 14); and Balaji v. State of Mysore, A.I.R. 1963 S.C. 649 (664)).

47. See infra note 101. 
favour of any backward class of citizens which, in the opinion of the State, is not adequately represented in the services under the State. ${ }^{48}$

Article 16(4), in addition to allowing the creation of quotas, gives the state the right to establish preferences for the promotion of untouchables in government employment. ${ }^{49}$ The landmark decision in State of Kerala v. N.M. Thomas ${ }^{50}$ established the government's right to create such special preferences for the Scheduled Castes and Scheduled Tribes in government employment. ${ }^{51}$ Quotas, however, must be within reasonable limits not only under the reasonable classification standard of Article 14, but also under Article 335, which states:

The claims of the members of the Scheduled Castes and the Scheduled Tribes shall be taken into consideration, consistently with the maintenance of efficiency of administration, in the making of appointments to services and posts in connection with the affairs of the Union or of a State..$^{52}$

Article 335, while recognizing the claims of the untouchables, places limitations on the extent to which the state can reserve places for the Scheduled Castes. ${ }^{53}$ Consequently, a balance must be struck between the number of places reserved for the Scheduled Castes in government employment and the number of those positions which are to be secured by competition or merit selection. ${ }^{54}$

48. See India Const. art. 16(4).

49. Galanter, supre note 2, at 370; see Rangachari v. General Manager, A.I.R. 1962 S.C. 36.

50. A.I.R. 1976 S.C. 490.

51. The Supreme Court held that the Article 16(2) prohibition of discrimination based on caste was not violated by the preferential system mandated by the state of Kerala since the "Scheduled Caste" is not a caste, but a category which is defined in accordance with constitutionally permissive criteria such as the "backwardness" of a group. Galanter, supra note 2, at 388 . Caste, however, may itself be considered as a sufficient indicia of backwardness upon which a Scheduled Caste designation may arise. Here, the Supreme Court created a legal fiction that conveniently distinguishes untouchables from Scheduled Castes which are, for practical purposes, analogous.

52. See India Const. art. 335.

53. See BAsu, supra note 38 , at 798.

54. Article 335 is limited in application to the Scheduled Castes and Scheduled Tribes and omits any mention of the Other Backward Classes. Galanter, supra note 2 , at 369 . Would this mean that the government would be free to establish quotas for the OBC without regard for "efficiency of administration"? This would not be the case as the Indian Supreme Court has stated that such a classification would not be in accordance with the reasonableness standards of Article 14 and 16(1). BAsU, supra note 38, at 798 (citing Balaji v. State of Mysore, A.I.R. 1963 S.C. 649). 
In India, quotas in educational and other state-run institutions were also a matter of controversy until the passage of Article 15(4). The creation of Article 15(4) was prompted by the decision in State of Madras v. Champakam Dorairajan. ${ }^{55}$ In Dorairajan, the Court held that reservations in educational institutions were in violation of Article 29(2) ${ }^{56}$ which prohibited educational institutions from denying admission to applicants based on religion, race, caste, or language. The Court maintained that special quotas on the basis of caste were violative of the prohibition against caste discrimination. ${ }^{57}$ Shortly thereafter, Article 15(4) was passed which effectively overruled Dorairajan.$^{58}$

While Articles 15(4) and 16(4) allow the state to make special provisions for untouchables, such allowances must also be viewed in the context of Articles 15(1) and 16(1). Article 15(1) provides that "the State shall not discriminate against any citizen on grounds only of religion, race caste, sex, place of birth or any of them." Article 16(1) which, like Article 16(4), specifically applies to government employment provides that " $t]$ here shall be equality of opportunity for all citizens in matters relating to employment or appointment to any office under the State." ${ }_{59}$

The Fundamental Rights of the Indian Constitution are presently interpreted in a way that promote substantive equality. ${ }^{60}$ This, however,

55. A.I.R. 1951 S.C. 226.

56. Id. Article 29(2) stated as follows: No citizen shall be denied admission into any educational institution maintained by the State or receiving aid out of State funds on grounds only of religion, race, caste, language or any of them.

57. Id.

58. BAsU, supra note 38 , at 56 .

59. In State of Kerala v. N.M. Thomas, A.I.R. 1976 S.C. 490, the State of Kerala argued that the special exemption went beyond the scope of Article 16(4) and was in violation of the general guarantee of equality in employment opportunities under Article 16(1). The Indian Supreme Court held that there was no contradiction between Article 16(1) and 16(4). The Court held that "equality" as embraced in Article 16(4) helped explain the concept of equality in Article 16(1).

60. Formal equality and substantive equality are two commonly distinguished concepts. Formal equality is the state in which "equality of opportunity" exists due to the absence of disabilities. See Singh, supra note 27, at 16-19. In contrast, substantive equality, which assumes that not all people are equal in abilities, emphasizes equality in results. Id. Take, for example, a situation where 50 individuals from Group $\mathrm{A}$ and Group B are composed of 25 individuals each. Further assume that all the members from each group are competing for 10 positions. If for the 10 positions, 5 individuals must be selected from both Group A and Group B, then substantive equality or equality of results is achieved. However, if the selection is based on who scores the highest marks on an exam, then our selection procedure achieves formal equality. The potential 
does not imply that the state has unbridled power to make classifications in favor of untouchables. ${ }^{61}$ The state may only create reasonable classifications $^{62}$ which do not, as stated in Article 335, interfere with "the maintenance of efficiency of administration." 63 Therefore, merit must also be taken into consideration ${ }^{64}$ and some balance must be reached between the reservations made for special groups and positions secured through strictly competitive means. ${ }^{65}$ It is important to realize that substantive equality is not promoted due to a staunch egalitarian philosophy, but as a result of both great injustices that groups like the untouchables have suffered and political considerations. It may be more appropriate to say in regard to the Indian Constitution that substantive equality operates within the general framework of formal equality. In Galanter's words, "The compensatory principle of substantive equality is added to the constitutional scheme of formal equality, but it does not displace it." 66 The Indian constitutional analysis thus finds a place

problem with formal equality is that it does not guarantee that the same number of individuals will be chosen from Group A and Group B. Conversely, the problem with substantive equality is that it does not guarantee that the individuals with the 10 highest scores will be selected.

61. The general rule had been that reservations may not exceed $50 \%$. Singh, supra note 27, at 192 (citing Balaji, A.I.R. 1963 S.C. 649). However, in Akhil Bharatiya Shoshit Sangh v. Union of India, A.I.R. 1981 S.C. 298, the Supreme Court held that a reservation scheme could not be "substantially" beyond $50 \%$. BAsu, supra note 46, at 798. In Akhil, the Court held that a quota of $64.4 \%$ was not excessive. See Basu, supra note 46, at 798. In Akhil, the Court expressed that the Balaji limit was not a strict limit. Samuel M. Witten, Note, Compensatory Discrimination In India: Affirmative Action As a Means Of Combatting Class Inequality, 21 Colum. J. Transnat'l L. 353 (1983).

62. See infra note 101 .

63. See India Const. art. 335.

64. See Singh, supra note 27 , at 213.

65. Id.

66. Galanter, supra note 2, at 561. In order to describe how Indian constitutional law has handled the concepts of formal and substantive equality in the same framework, Galanter quotes Glanville Austin as follows:

India's original contributions to constitution-making, [that is] accommodation . . . the ability to reconcile, to harmonize, and to make work without changing their content, apparently incompatible concepts - at least concepts that appear conflicting to the non-Indian, and especially to the European or American observer. Indians can accommodate such apparently conflicting principles by seeing them at different levels of value, or, if you will, in compartments not watertight, but sufficiently separate so that a concept can operate freely within its own sphere and not conflict with another operating in a separate sphere ... with accommodation, concepts and 
for what are often considered two contradictory notions of equality.

The major challenge facing the Indian constitution is whether its protections for the untouchables will be able to withstand the social upheaval over affirmative action. So far, the Indian constitution and the judiciary have remained a source of stability in an otherwise chaotic social and political environment.

\section{B. Constitutional Safeguards for Blacks}

In the United States Constitution, the Fourteenth Amendment was created with the intention of securing and upholding rights that had been given to the newly freed black slaves. ${ }^{67}$ The Equal Protection Clause of the Fourteenth Amendment prevented the states from discriminating against blacks. The states, however, were not necessarily obliged to better the status of the newly freed slaves. ${ }^{68}$ Unlike the Indian Constitution, the U.S. Constitution does not expressly legitimize affirmative action or "benign preferences." 69 The constitutional validity of affirmative action relies upon an implied justification for such benign classifications under the Equal Protection Clause. ${ }^{70}$

The landmark decision of Brown 0 . Board of Education of Topeka ${ }^{71}$ was a precursor for the development of affirmative action programs in the United States. In Brown, which overruled Plessy, the Court held that separate but equal was inherently unequal. The Brown ruling paved the way for other Supreme Court rulings which declared segregation violative of the Fourteenth Amendment. ${ }^{72}$ Once racial barriers such as segregation were legally removed, legal scholars questioned whether benign preferences ${ }^{73}$ for minorities such as blacks were constitutionally

viewpoints, although seemingly incompatible, stand intact. They are not whittled away by compromise but are worked simultaneously.

Id. at 561-62.

67. Strauder v. West Virginia; 100 U.S. 303, 306 (1879).

68. TRIBE, supra note 1 , at 1525 . In Plessy v. Ferguson, Justice Harlan stated that "[o]ur Constitution is color-blind ... ." 163 U.S. 537, 559. Opponents of affirmative action state that because the constitution is color-blind, "race specific setasides" violate the taboo against race-based preference. TRIBE, supra note 1 , at 152528.

69. "Benign" racial classifications refer to preferences for minorities. See Stone, supra note 15 , at 578 .

70. See Wasby, supra note 29 , at $\mathbf{3 8 0}$.

71. 347 U.S. 483 (1954).

72. See, e.g., Swann v. Charlotte-Mecklenburg Bd. of Educ., 402 U.S. 1 (1971).

73. Benign preferences refer to preferential treatment that minorities receive despite the theory that race classifications are supposed to be judged under strict scrutiny analysis. See supra note 69 and accompanying text; see infra p. 27. 
permissible. As Justice Matthew of the Indian Supreme Court states in his analysis of Brown:

Beginning most notably with the [United States] Supreme Court's condemnation of school segregation in 1954, the United States has finally begun to correct the discrepancy between its ideals and its treatment of the blackman . . . These actions while not producing true equality or even equality of opportunity logically dictated the next step: positive use of government power to create [the] possibility of real equality. ${ }^{74}$

One positive use of governmental power to create greater equality occurred with the passage of the Civil Rights Act of 1964. A key provision of this Act was Title VII (42 U.S.C. $\$ 2000 \mathrm{e}$ et seq.) which was enacted to combat race and other forms of discrimination in a number of employment settings, including private employment. ${ }^{75}$ The application of Title VII has generated heated debate. Opponents of affirmative action claim that Title VII has been interpreted to unjustly allow benign preferences for minorities which has resulted in "reverse discrimination" against the white majority. ${ }^{76}$

74. Singh, supra note 27 , at 52 .

75. Mark Rothstein et al., Employment Law Textbook 198-200 (1987). The underlying constitutional validity of Title VII is derived from the Fourteenth Amendment and the Interstate Commerce Clause U.S. Const. art. I, \$ 8). Id. at 19293 (citing Heart of Atlanta Motel v. United States, 379 U.S. 241 (1964) and Katzenbach v. McClung, 379 U.S. 294 (1964)).

The first case dealing with Title VII was seen in Griggs v. Duke Power Co., 401 U.S. 424 (1971). In Griggs, the Court held that the requirements of a high school diploma and satisfactory performance on a standardized test which adversely impacted on the selection of blacks could not be used as the criteria for job selection where such criteria had no relationship with the job skills demanded.

Indian law possesses no statutory analogue of Title VII. However, the former Untouchability (Offences) Act which was passed in 1955 and amended under the new title, "Protection of Civil Rights Act," prohibits discrimination against untouchables in public places of worship, hotels, shops, places of public entertainment, etc. See Hanuman Gupta, Protection of Civil Rights, 22-25 (1986). Also important to note is that in India, the great majority of employment is found in the government rather than the private sector. As India's economy adopts more capitalistic measures, however, the issue concerning whether legal protection for untouchables should be extended to employment in the private sector may become an important issue.

76. The fears of opponents of affirmative action had been substantially allayed by the U.S. Supreme Court's most recent decisions. See Francis T. Coleman, New Rules For Civil Rights, A.B.A. J., Oct., 1989, at 78-80. The Supreme Court made it more difficult for plaintiffs to prove Title VII violations. See Wards Cove Packing Company v. Antonio, 490 U.S. 642 (1989). The Court also made it more difficult to 
The prohibitions against discrimination stated in the Civil Rights Acts of 1964, its progeny, and various court decisions led to the establishment of affirmative action. Affirmative action faced its first serious challenge in Regents of the University of California v. Bakke." Bakke, the plaintiff, alleged that the quota employed by the medical college at the University of California at Davis was in violation of the Equal Protection. Clause of the Fourteenth Amendment, the California Constitution, and Title VI of the Civil Rights Act of 1964. The Court, in a 5-4 plurality opinion, ruled that racial quotas were illegal under Title VI. At the same time, the Court also held by a 5-4 vote that race could be used as a factor in an admissions program for the purpose of establishing a diverse student body.

In effect, Bakke left the door open for benign preferences to continue. ${ }^{78}$ The decision, however, failed to settle the constitutional controversy over affirmative action. Was affirmative action permissible under the Equal Protection Clause of the Fourteenth Amendment? Although the Court ruled that quotas were illegal, post-Bakke decisions cast some doubt on this position. ${ }^{79}$ Such devices as "temporary quotas" which are intended to achieve a certain percentage of minorities in the work force are, in essence, quotas. ${ }^{81}$ Under Title VII, mathematical ratios and "membership goals" ${ }^{82}$ have also been upheld.

The previous discussion of Bakke and other developments regarding quotas and benign preferences are especially relevant to legal scholars who desire to compare the U.S. and Indian affirmative action systems. Indian legal scholars often compare Bakke to Thomas. ${ }^{83}$ Both decisions dealt with "reverse discrimination" and took place at approximately the same time. While Bakke invalidated the use of quotas, Thomas clearly

justify quotas and other race-conscious remedies. See Martin v. Wilks, 490 U.S. 642 (1989). Time limitations within which challenges to alleged Title VII violations could be brought had also been reduced. Lorance v. AT\&T Technologies, 490 U.S. 900 (1989). The Civil Rights Act of 1991, P.L. 102-166, 105 Stat. 1071 (1991), however, has effectively overturned these decisions.

77. 438 U.S. 265 (1978).

78. See Tribe, supra note 1 , at 1528-30.

79. Tribe, supra note 1, at 1521-44 (citing United States v. Paradise, 480 U.S. 149 (1987)).

80. United States v. Paradise, 480 U.S. 149 (1987).

81. TRIBE, supra note 1 , at 1531-44.

82. Local 28, Sheet Metal Workers Int'l Ass'n v. EEOC, 478 U.S. 421 (1986). See also United Steelworkers of America v. Weber, 433 U.S. 193 (1979); Fullilove v. Klutznick, 448 U.S. 448 (1980).

83. See Singh, supra note 27 , at $66-71$. 
upheld them. Still, Bakke did not invalidate the use of benign preferences since it allowed race to be considered a factor in the admissions process. The Indian legal scholar, Parmanand Singh, observed that "Bakke is indeed a real victory for the civil rights proponents who were afraid that if the Court had ruled that use of race in any form and in any circumstances is impermissible then the whole 'affirmative action' policy would have collapsed." ${ }^{84}$ Whether Bakke and subsequent decisions favoring minorities will remain valid precedent under the Rehnquist Court is still uncertain. ${ }^{85}$

In the area of employment law, the Civil Rights Act of 1991 has overturned a number of recent Supreme Court decisions that greatly curtailed the effectiveness of proving racial and sexual discrimination. The U.S. Supreme Court's latest decisions made it more difficult to prove racial discrimination under Title VII. ${ }^{86}$ In Wards Cove Packing Company v. Antonio, ${ }^{87}$ for example, the Court held that statistics of disparate impact on minorities were not sufficient to form a prima facie case of discrimination. The Court stated that to prove racial discrimination, the plaintiff must be able to identify the alleged discriminatory practice and prove that nondiscriminatory reasons given by the defendant are only pretexts for discrimination. The passage of the Civil Rights Act of 1991 has effectively overturned Wards Cove. ${ }^{88}$

84. Singh, supra note 27 , at 69 .

85. In City of Richmond v. J.A. Croson Co., 488 U.S. 469 (1989), the Court struck down a Richmond city ordinance which required contractors to subcontract $30 \%$ of the monetary value of their city construction projects to minorities as violative of the Equal Protection Clause of the Fourteenth Amendment. The Court found insufficient proof of discrimination in the construction industry to justify such an affirmative action program.

86. Id. at 78-80. The Rehnquist Court had undercut the effectiveness of affirmative action in a number of indirect ways as well. For instance, in Patterson v. McLean Credit Union, 491 U.S. 164 (1989), the Court held that 42 U.S.C. 1981, which prevents racial discrimination involving contractual relations in areas such as employment, only applies in the hiring process. According to the Court, the statute would not bar discrimination after employment had been secured. Therefore, the statute would have been ineffective against employers who dismissed an employee on racial grounds. The Civil Rights Bill, however, has overturned the Patterson decision. The Civil Rights Bill restored the previous expansive interpretation of the statute which prohibits racial discrimination in the workplace as well.

87. 490 U.S. 642 (1989).

88. The passage of the Civil Rights Act of 1991 reinstated the standard provided in Griggs v. Duke Power Co., 401 U.S. 424 (1971), for determining whether an employer has engaged in discrimination. Under Griggs, to prove racial or sexual discrimination, the plaintiff must demonstrate that the hiring practices of the defendant- 
Both Indian and American law has tried to incorporate substantive equality into a framework of formal equality. ${ }^{89}$

\section{Cross Gultural Influences in Relation to Affirmative Action}

In the past, cultural exchanges between the United States and India have occurred. For example, the great nineteenth century American philosopher, Henry David Thoreau, was influenced by Hindu philosophy. ${ }^{90}$ In return, Thoreau's famous book, Civil Disobedience, provided Gandhi with key insights on creating his own strategy of civil disobedience against the British in India. ${ }^{91}$ Subsequently, Dr. Martin Luther King, Jr., derived inspiration and guidance from Gandhi's philosophy in leading the civil disobedience campaign in the United States. ${ }^{92}$

The U.S. and Indian affirmative action systems are both domestic products; ${ }^{93}$ yet the evolution of the affirmative action system in each country has not been completely isolated from the other. For instance, Indian legal scholars and judges have been well aware of the origin and development of affirmative action in the United States. ${ }^{94}$ Many of

employer have a disparate impact on the selection of qualified minorities. Upon the production of such evidence, the defendant-employer must prove that the hiring practices that have a disparate impact on the selection of minorities are justified by business necessity. A hiring criterion is justified under business necessity if it is shown to be related to successful performance on the job. Even upon a showing of business necessity, the plaintiff will still prevail if she can show that less discriminatory hiring practices that are also indicative of successful job performance were available to the defendant.

89. President Bush, for instance, emphasized that he would veto the Civil Rights Bill of 1991 if it were a quota bill. Richard L. Alfred \& Thomas A. Knowlton, Civil Rights Act will Encourage Federal Claims; the Civil Rights Act of 1991, Mass. Law. WkLY., Dec. 9, 1991, at 5. Although President Bush had political motives in advancing such an argument, the passage of the Civil Rights Act of 1991 will not only be more favorable towards minorities but will also lead to greater outcries of reverse discrimination. Benign preferences will continue while formal equality will always be stated as the goal.

90. Chester Bowles, What We Can Learn Fram Gandhi, in Profiles of Gandhi 194 (Norman Cousins ed., 1969).

91. Id. at 193.

92. Id.

93. As Professor Galanter states, India's affirmative action program was built from scratch. Gadbois, supra note 26, at 344.

94. See Sing h, supra note 27, Ch. III. See also Rajeev Dhavan, Borrowed Ideas: On The Impact Of American Scholarship On Indian Law, 33 Ам. J. Сомр. L. 505-26 (Professor Dhavan discusses the general influences that American scholarship has had on Indian law). 
the principles underlying the U.S. Constitution have been incorporated into the Indian Constitution. ${ }^{95}$ American constitutional law has influenced not only Indian constitutional law in general, but also Indian affirmative action law in particular. ${ }^{96}$ Interestingly, Indian influences on the development of affirmative action in the United States can also be detected. These subtle Indian influences will be explored in detail. In comparison, the American influences in relation to Indian affirmative action are well documented by both American and Indian legal scholars. ${ }^{97}$

\section{A. American Influences on the Development of Indian Affirmative Action}

The most significant American influence on Indian affirmative action is the incorporation of the language of the Equal Protection Clause of the Fourteenth Amendment into Article $14 .^{98}$ Article 14 states that "The State shall not deny to any person . . . the equal protection of the laws." '99 Unlike the Fourteenth Amendment which lends questionable support to affirmative action, Article 14 has been read to actually endorse affirmative action. The Indian Equal Protection Clause, similar to its American counterpart, applies only to state action. ${ }^{100}$ Article 14 analysis has employed the "rational basis test," as used in equal protection analysis under the Fourteenth Amendment. ${ }^{101}$ In both

95. See Robert B. Charles, Special Project, American Influence on the Indian Constitution: Focus on the Equal Protection of the Laws, 17 Colum. Hum. Rts. L. Rev. 193, $193(1985 / 86)$. For instance, many of the underlying principles of the fundamental rights found in the Bill of Rights of the U.S. Constitution have been incorporated into the Indian Constitution. Id.

96. Id. at 197.

97. Gadbois, supra note 26 , at 361 .

98. See Katz, supra note 33, at 613 n.10; Charles, supra note 95, at 193.

99. Charles, supra note 95, at 194. The omitted portion of Article 14 which states "equality before the law" is a British concept. The Equal Protection Clause is given greater importance in construing the meaning of Article 14. Id.

100. Basu, supra note 46 , at 12,25 .

101. Sinch, supra note 27, at 23-24. In short, the rational basis test looks at whether the statute in question intends to achieve any legitimate end and whether the statute helps to achieve the end in any conceivable manner possible. TRIBE, supra note 1 , at 1439-43.

The Indian rational basis test which is referred to as the "reasonable basis test" is not analogous to the rational basis test applied in U.S. constitutional law. In judging whether a classification for backward classes satisfies the "reasonable basis test," the Court will apply the following two step approach:

(i) the classification must be founded on intelligible differentia which distinguishes persons or things that are grouped together from others left out 
countries, the rational basis test provides a method of evaluating the constitutional validity of legislation. ${ }^{102}$ This standard of review automatically gives great deference to the legislature. ${ }^{103}$ In Indian constitutional law, the rational basis test would, for example, be used in determining whether quotas created for untouchables satisfied the equal protection guarantee of Article 14. ${ }^{104}$

Indian equal protection analysis, however, has not adopted any "strict scrutiny" standards, such as the "compelling state interest" test or "intermediate scrutiny." 105 The Indian legislature considered the rational basis test sufficient because, unlike in the United States, legislation has seldom been used as a means of discrimination against untouchables. ${ }^{106}$ The purpose of strict scrutiny was to subject legislation that discriminated on the basis of race or other "suspect classifications" to a higher judicial standard of constitutional review. ${ }^{107}$ According to one scholar, in India, the fear is not so much from state-sponsored discrimination as it is from social discrimination. ${ }^{108}$ India's omission of "strict scrutiny" also avoids the problem of determining which standard of review to apply to "benign classifications" or legislation favorable to minorities; since affirmative action is rooted in the Indian Constitution, benign preferences are more likely to satisfy the rational basis test.

Although Indian judges have cited U.S. affirmative action decisions and law review articles in their opinions, ${ }^{109} \mathrm{U}$.S. case law has not been cited as legal precedent. It has, nevertheless, been used to support the view that affirmative action can exist alongside a constitutional system which stresses equality. ${ }^{110}$

American influence on Indian legal scholars began as India was in the process of creating a constitution. For example, Mr. B.N. Rao, the Indian constitutional advisor, visited the United States and solicited

of the group and

(ii) that differentia must have a rational relation to the object sought to be achieved by the statute in question.

BAsU, supra note 38 , at 27.

102. Nowak \& Rotunda, supra note 31 , at 574-75.

103. Id.; BASU, supra note 38 , at $44-45$.

104. See Singh, supra note 27 , at 28,41 .

105. See Charles, supra note 95, at 195, n.6 and p. 206.

106. Id. at 208-09.

107. J. Barron et al., Constitutional Law $488-98$ (1987).

108. See Charles, supra note 95, at 208-09.

109. Wasby, supra 29 , at 384-85.

110. Singh, supra note 27 , at 53 . 
the views of many influential American judges and scholars. ${ }^{111}$ Arguably, the most prominent Indian to be influenced by the United States was Dr. B.R. Ambedkar, the great untouchable scholar and Chairman of the Constitutional Committee. ${ }^{12}$ Ambedkar, while at Columbia, was inspired by such legal constructs as the Fourteenth Amendment which had guaranteed blacks greater freedoms. ${ }^{113}$ One of Ambedkar's American heroes was Booker $\mathrm{T}$. Washington, the black reformer and educator. ${ }^{114}$ Ambedkar's revolution for the emancipation of untouchables was significantly influenced by American ideals of equality. ${ }^{115}$

\section{B. Indian Influences on the American Caste System and Affirmative Action}

American legal scholars might be somewhat skeptical of suggestions of any Indian influence on the U.S. legal system. ${ }^{116}$ It is thus with caution that one must approach such a discussion. Nevertheless, a number of Indian influences on American culture may be noted which have had more than a tenuous connection with the U.S. legal system when viewed from a broad social science perspective.

A logical place to look for the possibility of Indian influence would be in the creation of affirmative action in the United States. Despite the fact that India started affirmative action before the United States, ${ }^{117}$ there is no proof that the United States was in any way influenced by India's affirmative action philosophy. It is interesting to note that former Mayor Ed Koch of New York City felt that quotas in the United States were an imitation of India's system of preferential treatment. ${ }^{118}$ Affirmative action in the United States, however, is an indigenous product.

Some Indian influence may be found in the introduction of caste terminology into the United States in both social and legal contexts.

111. Charles, supra note 95 , at 204-05.

112. Dr. Ambedkar, who collected a remarkable number of degrees and honors, studied at Columbia University in 1916 and also attended colleges in India and Great Britain.

113. W. Kuber, B.R. Ambedkar 21 (1978).

114. Id. at 22.

115. It is interesting to note that a Post-Ambedkar movement named the "Dalit Panthers" sprang up India which was patterned after the Black Panther movement among the blacks in the United States.

116. Gadbois, supra note 26 , at 362 .

117. Galanter, supta note 2, at xvii.

118. Weiner \& Katzenstein, supra note 11 , at 21. 
For instance, the term "Boston Brahmin" 119 was used in the United States in the early part of the nineteenth century. ${ }^{120}$ This term was often used to describe the "cultured" individuals of New England, such as Harvard intellectuals. Henry David Thoreau, along with other mid-nineteenth century philosophers in the Boston area, such as Emerson and Alcott, were literally "Brahmins" in behavior. ${ }^{121}$ In more recent times, we have seen social scientists and legal scholars using descriptions such as "racial caste system,", 122 "color caste system," "sexual caste system," "124 "caste system," "125 “caste," "126 and many other related terms to describe the status of blacks and other groups in the United States. The term "caste legislation" ${ }^{127}$ has been used to describe discriminatory statutes. Justice Marshall's dissent in Kadrmas v. Dickinson Public Schools"28 maintained that "the intent of the Fourteenth Amendment was to abolish caste legislation." 129 The introduction of caste terminology into American English is hardly surprising. In the early part of the nineteenth century, Herbert Risley, a prominent anthropologist, vividly described the similarities in status of untouchables and black slaves in the United States. Such comparisons, which have generated a great deal of controversy, continue to the present time. Gerald Berreman, a well known anthropologist from the University of California at Berkeley, argues that "caste" may be given a cross-cultural definition

119. A Dictionary of Americanisms: On Historical Principles 302 (1938). The Brahmin class represented the intellectuals within the traditional Hindu caste hierarchy. See supra text accompanying note 6.

120. Id.

121. All three early American philosophers were influenced by Hinduism. UMESH Patri, Hindu Scriptures and American Transcendentalists 10-15 (1987). Thoreau, in particular, was influenced by such Indian texts as "The Laws of Manu" and the "Bhagavad Gita." Id. at 99. Ironically, these texts perpetuated the philosophy underlying the caste system.

122. Raymond T. Diamond \& Robert J. Cottrol, Codifying Caste: Louisiana's Racial Classification Scheme and the Fourteenth Amendment (Doe v. Louisiana), 29 LoY. L. REV. 255 (1983).

123. MYRDAL, supra note 24 , at 676 .

124. See Jo Freeman, Legal Basis of the Sexual Caste System, 5 VAl. U. L. Rev. 203 (1971).

125. See United States v. Yazell, 382 U.S. 341 (1966).

126. See Plyler v. Doe, 457 U.S. 202 (1982); Sales v. U.S. 258 F. 597 (1919).

127. See Kadrmas v. Dickinson Public Schools, 487 U.S. 450 (1988) (citing Plyler v. Doe, 457 U.S. 202 (1982)).

128. Id.

129. Id. 
to encompass discrimination against blacks in the United States. ${ }^{130}$ At the same time, "caste" may be given such a narrow definition as to be applicable only to Hinduism. ${ }^{131}$ No matter how one defines caste, it is evident that blacks and untouchables experience similar forms of discrimination.

A well documented mention of "caste" in American legal literature is found in Justice Harlan's dissent in Plessy v. Ferguson ${ }^{132}$ where he stated:

[I]n the view of the Constitution, in the eye of the law, there is in this country no superior, dominant, ruling class of citizens. There is no caste here. Our Constitution is color-blind ....133

Yet he contradicted his own observation that " $[t]$ here is no caste here" in the same opinion, when he observed just prior to the quoted excerpt that:

The white race deems itself to be the dominant race in this country. And so it is, in prestige, in achievements, in education, in wealth and in power. So, I doubt not, it will continue to be for all time.....134

Justice Harlan's view of white supremacy was no different than an orthodox Brahmin's. sense of superiority over untouchables. In this regard, Justice Harlan's views of race relations was highly caste-oriented. Moreover, even if Justice Harlan had been whole-heartedly opposed to a caste system, his opinion stood alone as the sole dissent. The majority did not agree with Justice Harlan's basis for giving equal treatment to blacks.

The previous discussion on caste terminology used in social and legal contexts is not intended to present the notion that the United States has been influenced by caste discrimination as it exists in India. Rather, the intent is to demonstrate that Americans have, at times, seen it fit to describe discrimination or elitism in their society by using caste terminology associated with the Indian caste system.

India's most important influence on the United States in sociolegal terms lies in Gandhi's contribution to the black Civil Rights

130. Berreman, supra note 24 , at 1-2.

131. Id. at 2.

132. 163 U.S. 537 (1896).

133. Id. at 559 (emphasis added).

134. Id. 
Movement of the 1960's. ${ }^{135}$ While Gandhi was a leading advocate of the untouchable movement for equality, ${ }^{136}$ he also greatly influenced many black civil rights leaders. Dr. Martin Luther King, Jr., openly acknowledged borrowing Gandhi's civil disobedience strategy in his civil rights campaigns. ${ }^{137}$ While most scholars of the Civil Rights movement are well aware of Gandhi's influence on King, Gandhian influence on the black rights movement took place a generation before King's arrival.

In the mid-1930's, influential black leaders visited Gandhi, who was in the process of waging India's civil disobedience campaign against the British. For example, leading black spokespersons, such as Channing Tobias and Benjamin Mays (who would eventually give King's eulogy), visited Gandhi in India in 1937 to discuss the status of black Americans. ${ }^{138}$ Gandhi, when asked about his forecast for blacks in the United

135. In addition to Gandhi's influence on the black civil rights movement, Mrs. Indira Gandhi, the late Indian Prime Minister (and no relation to "Mahatma"' Gandhi), had been a source of inspiration for American women who had yet to achieve prominence in any major political post. Mrs. Gandhi had consistently ranked as one of the most respected leaders in the United States. See N.Y. Times, Dec. 31, 1969, at 9; N.Y. Times, May 7, 1971, at 25; N.Y. Times, Dec. 27, 1973, at 44.

136. Some have criticized Gandhi for his views on untouchability. Gandhi, for instance, labelled the untouchables as "harijans" which means "children of God." Some viewed Gandhi's use of this term as having a patronizing effect on untouchables. Another area of criticism regarding Gandhi stemmed from his belief that Hinduism could be maintained as an integral and intact religion while ridding itself of caste discrimination at the same time. Gandhi believed that caste discrimination was a perversion of Hinduism. See Galanter, supra note 2, at 29. He advocated the notion held by some Hindus that the caste system was supposed to view all castes as equal. Much of the criticism raised against him, however, is unwarranted. Gandhi was clearly a supporter of the untouchable movement for equality. He angered many high caste Hindus by breaking the caste code of segregation and living directly with untouchables in the most miserable of conditions. See John Gunther, Mr. Gandhi, in Profiles of Gandhi 47-48 (Norman Cousins ed., 1969); Eleanor Roosevelt, At Gandhi's Shrine, in Profiles of Gandhi 159. See also Edgar Snow, The Message of Gandhi, in Profiles of GandhI 106; Robert Trumbell, $A$ Last Birthday Reminiscence, in Profiles of GandhI 67; Bowles, supra note 90 , at 162 . It was in an untouchable village that he established the center for his movement. His newspaper was entitled the "Harijan". Homer Jack, Gandhi and Martin Luther King, in Profiles of Gandhi 219. Many Indians thought that Gandhi had lost his senses when he advocated the idea that India's first President should be an untouchable woman. Trumbell, supra, at 67. Gandhi may be more aptly described as a proud Hindu, who was deeply inspired by his religion (see Vincent Sheean, Tribute from 'A Last Disciple', in Profiles of Gandhi 75) and felt a need to preserve it while at the same time purging it of its negative aspects.

137. Martin Luther King, Jr., Pilgrimage To Nonviolence, in Profiles of Gandhi 206-17 (Norman Cousins ed., 1969).

138. Jack, supra note 136, at 219. 
States, replied that "[w]ith right which is on their [black Americans] side and the choice of non-violence as their only weapon, if they will make it such, a bright future is assured."139 A year earlier, in 1936, Howard Thurman, a famous black preacher and educator, visited Gandhi and urged him to come to the United States to fight for black rights. ${ }^{140}$ During Thurman's visit, various problems such as racial segregation and voting rights in the United States were discussed. ${ }^{141}$ Thurman later stated, "In his experiments with Truth as they expressed themselves in the social and political struggle of India for freedom, $\mathrm{Mr}$. Gandhi provided a crucial point of reference for the American Negro in his social and political struggle for freedom."142 Six years after Thurman's visit with Gandhi, James Farmer, one of Thurman's students and a leading civil rights activist, established the Congress of Racial Equality (CORE) in the United States which was based on Gandhian philosophy. ${ }^{143}$

Gandhian philosophy had been a great source of inspiration for the founders of CORE. 144 Shridharani's War Without Violence, which described Gandhian civil disobedience, provided CORE members with a strategic basis for how the organization would battle racism. ${ }^{145}$ The peak of CORE's success came with its launching of the Freedom Ride

139. Id.

140. Gandhi, however, declined as he felt he had not accomplished his goals in India. Howard Thurman, A Plea From Black America, in Profiles of Gandhi 45. According to Homer Jack, Mr. and Mrs. Thurman asked Gandhi to come to the United States "not for White America, but for the Negroes; we have many a problem that cries for solution, and we need you badly." Jack, supra note 136, at 219.

141. Thurman, supra note 140 , at $43-44$.

142. Id. It is also interesting to note that Gandhi, according to Dr. Thurman's account, said that "it may be through the Negroes that the unadulterated message of nonviolence will be delivered to the world." Id. at 45. In the 1960's, Dr. Martin Luther King, Jr., through his Gandhian nonviolent movement, secured many new freedoms for blacks and also won the Nobel Peace Prize in 1964 for his efforts.

143. Thurman, supra note 140 , at 45 ; Jack, supra note 136, at 219 . CORE was one of the leading civil rights groups of the 1960's along with the National Association for the Advancement of Colored People (NAACP), the Southern Christian Leadership Conference (SCLC), the Student Nonviolent Coordinating Committee (SNCC). All of these groups had employed the nonviolent technique of civil disobedience during their civil rights campaigns. August Meier \& Elliott Rudwick, A Study in the Civil Rights Movement 3 (1975) [hereinafter MEIER].

144. Four among the six founders of CORE were white. MEIER, supra note 143, at 5. It is interesting to note that many of the original and leading advocates for untouchables rights were Brahmins. Gadbois, supra note 26, at 354.

145. Id. at 6. 
of $1961 . .^{146}$ The Freedom Ride involved teams of blacks and whites traveling to the South to challenge segregation and racism by such civil disobedience ${ }^{147}$ techniques as picketing, ${ }^{148}$ boycotting, ${ }^{149}$ sit-downs, ${ }^{150}$ and jail-ins $^{151}$. These techniques reaped the same media success for the civil rights groups ${ }^{152}$ as they had for Gandhi. ${ }^{153}$

Gandhian philosophy and techniques were also successfully utilized by Cesar Chavez. ${ }^{154}$ Chavez, arguably the most famous contemporary Chicano rights leader in the United States, ${ }^{155}$ led his multiracial farm laborers' organization in defying exploitative laws. Like Gandhi, Chavez engaged in fasting ${ }^{156}$ and organizing long distance marches to attract international attention to the plight of grape workers in the Southwestern United States. ${ }^{157}$ Both King and Chavez had successfully introduced the Gandhian concept of "satyagraha" to their respective ethnic groups which represent the two largest minorities in the United States. ${ }^{158}$

The concept of "satyagraha" or nonviolent direct action, ${ }^{159}$ the Gandhian term for civil disobedience adopted by CORE, ${ }^{160}$ was most effectively applied by King. ${ }^{161}$

146. Id. at 135 .

147. Id. at 136. Meier and Rudwick state that "tactically the Ride was the culmination of the use of the Gandhian jail-no-bail principle first employed in 1960 and most recently applied with such stunning effect at Rock Hill." Id.

148. Id. at 12, 63; see also Jack, supra note 136, at 221.

149. MeIER, supra note 143 , at 12,63 .

150. Id. at 12; Jack, supra note 136, at 221.

151. Jack, supra note 136, at 221; MEIER, supra note 143, at 106, 139.

152. Bowles, supra note 90 , at 197.

153. Id. at 196-99. Bowles mentions how the news of Gandhi's salt march "flashed" across India to even the most remote villages. The effect of the news was to create greater social involvement in Gandhi's nonviolent movement. Similarly, the media's coverage of King's nonviolent movement in the South led to a national consciousness and sympathy for the civil rights movement in the United States. Id.

154. Wintrop. Yinger, Cesar Chavez: The Rhetoric of Nonviolence 20, 25 , $34,76,84$ (1975).

155. See Joan London \& Henry Anderson, So Shall Ye Reap 170 (1970). Chavez became a symbol of "la raza" or brown consciousness within the MexicanAmerican community. Id.

156. YINGER, supra note 154 , at 84 .

157. Id. at 28.

158. Chavez has been called "The Mexican Martin Luther King." Id. at 20 (quoting Steven Roberts, Grape Boycott: Struggle Poses a Moral Issue, N.Y. Times, Nov. 12, 1969, at 43). King complimented Chavez for being a "living example of the Gandhian tradition." London \& ANDErson, supra note 155 , at 184 . Both King and Chavez kept a portrait of Gandhi in their office.

159. MeIER, supra note 143 , at 4.

160. Id. at 4, 11-12. 
Satyagraha is best described in the following quote from King:

The Negro must come to the point that he can say to his white brothers: 'We will match your capacity to inflict suffering with our capacity to endure suffering. We will meet your physical force with soul force. We will not hate you, but we will not obey your evil laws. We will soon wear you down by our capacity to suffer. So, in winning the victory, we will not only win freedom for ourselves but we will so appeal to your heart and conscience that you will be changed also. The victory will be a double victory; we will defeat the evil system and win the hearts and souls of the perpetrators of the evil system.' ${ }^{162}$

Satyagraha was a militant form of nonviolence which, in King's words, sought to defeat "evil" through the use of "righteousness." Instead of stressing a battle between blacks and whites, joint action by both races was emphasized in fighting racism. ${ }^{163}$ For this reason, King was able to gain sympathy from whites without which a successful movement would have been unlikely. ${ }^{164}$

The success of the Civil Rights Movement led to the passage of the Civil Rights Act of 1964 and the Voting Rights Act of 1965. ${ }^{165}$ If King's movement and CORE had not employed Gandhian techniques, it is unlikely that the Civil Rights Acts would have come into existence within such a relatively short period of time. ${ }^{166}$ For example, if King had advocated the use of violence against the white majority, the American public would have been less sympathetic to his movement. ${ }^{167}$

160. Id. at $4,11-12$.

161. Jack, supra note 136 , at 219.

162. Bowles, supra note 90 , at 197-99.

163. See King, supra note 137, at 210, 214; Bowles, supra note 90, at 199.

164. Bowles, supra note 90, at 199. Here, Bowles mentions how the majority of white Americans were appalled by the violent reaction of southern bigots against the Civil Rights Movement. Bowles states that the only way to achieve racial harmony in the United States is by "a great moral force" by which the Gandhian method is implied. Id. King himself said, in reference to Gandhian techniques, "The aftermath of nonviolence is the creation of the beloved community, while the aftermath of violence is tragic bitterness." King, supra note 137 , at 210 .

165. MeIER, supra note 143 , at 431 .

166. Cf. Meier, supra note 143, at 431 (Meier states that direct action techniques, also known as "satyagraha" (see supra p. 43 and infra note 199), led to the passage of the Civil Rights Act of 1964). Id.

167. The failure of a violent movement to generate much sympathy was definitely 
This, in turn, would have provided Congress with less incentives to give blacks greater rights. A violent civil rights movement could have been portrayed by the media as racial warfare instead of a peaceful campaign whose members were the victims of violent southern bigots. A violent civil rights movement would have made the United States a more divisive society. ${ }^{168}$ Had King advocated violence, he would not have received the Nobel Peace Prize and gained the moral fervor needed to generate international sympathy. In essence, Gandhian techniques enabled the Civil Rights Movement to achieve its major victories, such as the passage of the Civil Rights Acts. The Civil Rights Act of 1964 in turn led to the creation of affirmative action programs. Affirmative action, thus, did not spontaneously arise, but had its roots in the Civil Rights struggle. The chain of events just discussed reveals a vital connection between Gandhi's influence on the Civil Rights Movement and the eventual creation of affirmative action programs in the United States.

\section{Future Interaction Between the United States and India}

Both the U.S. and Indian affirmative action systems function in similar political environments. Both countries are ethnically and culturally pluralistic societies which have a democratic form of government and similar judicial systems. There is also a great deal of controversy over the fairness of affirmative action in both societies. For example, certain Indian states have experienced riots and other forms of violent protest over affirmative action. ${ }^{169}$ Despite the Indian government's support for affirmative action, social support has been much more di-

known to King. As King stated:

A mass movement of a militant quality that is not at the same time committed to nonviolence tends to generate conflict .... The support of the participants and sympathy of the uncommitted are both inhibited by the threat that bloodshed will engulf the community. This reaction in turn encourages the opposition to threaten and resort to force. When, however, the mass movement repudiates violence while moving resolutely toward its goal, its opponents are revealed as the instigators and practitioners of violence if it occurs. Then public support is magnetically attracted to the advocates of nonviolence, while those who employ violence are literally disarmed by overwhelming sentiment against their stand. King, supra note 137, at 214.

168. See id.

169. John Wood, Reservations in Doubt: The Backlash Against Affirmative Action in Gujarat, India, 60 PAC. AfF. 408 (1987). 
vided. ${ }^{170}$ The idea of reverse discrimination generates controversy among Indians and Americans alike. Due to the political and social similarities that exist in both countries in regard to affirmative action, the potential for continued future interaction is significant.

Whether future interaction between the United States and India will be bilateral or unilateral is an important question. The Indian legal community, if not directly influenced by the U.S. Supreme Court decisions and legislative schemes, will most likely continue to be aware of and influenced by legal events that affect affirmative action in the United States. ${ }^{171}$ On the other hand, whether the United States can learn anything from India's lengthy experience with affirmative action remains an open question. ${ }^{172}$ India's repertoire of experience with affirmative action should serve as a good reference for the United States in accessing its own affirmative action programs. ${ }^{173}$

India could particularly benefit from researching the American judicial encounter with the implementation of affirmative action laws and programs. ${ }^{174}$ The American judiciary has played a significant role

170. Dr. Lalit Kumar Kashyap, Assistant Director of the National Commission for Scheduled Castes and Scheduled Tribes, states that the controversy is likely to continue well into the future as compensatory discrimination is here to stay.

Prime Minister Singh had made proposals to increase the scope of preferences to include groups based on minority status and low income level. See Times of INDiA, Aug. 10, 1990, at 1 . The Singh government, however, lost in the subsequent election. The Indian Supreme Court has recently held that an income test for the purpose of determining the beneficiaries of preferential treatment was permissible. See Times of INDIA, Feb. 1, 1990, at 3.

171. Anthony Lester, The American Constitution: Home Thoughts from Abroad, 49 U. Prtr. L. Rev. 769, 771 (1988).

172. As to the question of what the United States can learn from India's experience with affirmative action, Professor Galanter states, "Perhaps the most important lesson is that there is no single big lesson." Galanter, supra note 2, at 563 .

173. The similarities in the legal and social debates over affirmative action in India and the United States have been noted by a few scholars. In 1975, Professor Kent Greenwalt made the following observation:

The philosophical, legal and practical problems raised by preferences for disadvantaged groups are not limited to the United States. When one reads about debates over the systematic preferences in government jobs and university positions for those previously in the "untouchable" caste in India, one is struck by the similarity to the competing arguments voiced in this country.

Kent Greenwalt, Judicial Scrutiny of "Benign"' Racial Preferences in Law School Admissions" 75 Colum. L. Rev. 559, 559 n.1 (1975).

174. One important area which is beyond the scope of our discussion involves affirmative action for women in India. While quotas also exist for women (GALANTER, 
in shaping the development of affirmative action and civil rights. U.S. courts have demonstrated a willingness to exercise judicial review and judicial activism in implementing the laws as they have perceived them. If India is to remedy the continuing discrimination against untouchables and the politics involved in selecting the beneficiaries under the $\mathrm{OBC}$, then the Indian Supreme Court as well as the High Courts must exercise greater discretion over the implementation of affirmative action policies. ${ }^{175}$ The Indian Supreme Court is capable of exercising greater judicial review of affirmative action programs. ${ }^{176}$ The Indian Supreme Court possesses judicial review over a broad jurisdiction including the enforcement of the constitutionally mandated affirmative action provisions. ${ }^{177}$

One area where greater judicial review would greatly benefit the politically plagued affirmative action system is in the selection of the OBC. The selection process by which groups are categorized under the $\mathrm{OBC}$ is highly politicized. ${ }^{178}$ Abuses in the selection process result in resources being diverted from the truly needy members of the OBC and the untouchables. The states' discretion in determining beneficiaries under the $\mathrm{OBC}$ must be placed under greater judicial scrutiny. The Supreme Court, which possesses the power to establish jurisdiction over the states' discretion in the selection of the OBC, ${ }^{179}$ needs to provide clearer guidelines as the selection criteria for the OBC. ${ }^{180}$ The problem of the Court's overloaded docket could be solved by creating judicial agencies under the Court's authority which would monitor the states' selection procedures. Greater judicial enforcement in the selection of the $\mathrm{OBC}$ would create increased efficiency in allocating resources to deserving beneficiaries.

supra note 2, at 426; Weiner \& Katzenstein, supra note 11, at 32), India has a poor record in the area of women's rights. With the rise of women's rights groups in India, Indian policy makers and scholars would greatly benefit from researching the American legal experience in attempting to achieve equality between the sexes.

175. See Gadbois, supra note 26 , at 353.

176. Gadbois, supra note 26 , at 350 .

177. Id.

178. See Gadbois, supra note 26 , at $351-57$.

179. Due to the greater possibility of judicial abuse in judging OBC membership at the state level (Gadbois, supra note 26, at 351-52), it would be wiser to give the Supreme Court greater discretion in determining the OBC. The Supreme Court has established a fairly good reputation as a politically neutral branch of government. Id. at 351. Supreme Court Justices are chosen for a life term and cannot be removed without cause. The executive and legislative branches have been especially deferential to the Court's decisions in the area of fundamental rights. Id.

180. See Gadbois, supra note $26,356-59$. 
Judicial activism is not a panacea for the great abuses that untouchables continue to suffer in India. However, the judiciary will provide greater checks for possible abuses. While the other branches of government must concern themselves with the political repercussions of their actions, the judiciary is the one branch of government which can act without taking political whims into consideration.

Implementation of anti-discrimination laws is another area in which India needs great improvement. Major questions exist as to how effective anti-discrimination laws are in protecting untouchables. While the judicial system is easily accessible to untouchable litigants, ${ }^{181}$ some of the greatest injustices are never brought to its attention due to the ignorance among victims regarding legal options. The scope of judicial involvement and enforcement of anti-discrimination laws could be increased through the implementation of agencies such as the Civil Rights Division of the Justice Department and the Equal Employment Opportunity Commission, which are found within the U.S. government. ${ }^{182}$ Although these agencies have not always been effective in addressing the problems of discrimination in the United States, they would at least help to identify some of the more serious problems of discrimination which could, in a country like India, go unnoticed. Such enforcement agencies may also give incentives to apathetic administrators to actually abide by the existing laws. ${ }^{183}$ Without such agencies, the means by which anti-discrimination laws are enforced become much weaker.

Awareness of the successes and failures of India's affirmative action programs may provide the United States with an idea as to what policies may be desirable or undesirable in relation to the existing political and social environment. ${ }^{184}$ India's experience with affirmative action may

181. See Galanter, supra note 2, at 498-99.

182. Galanter, supra note 2, at 541-42; Wasby, supra note 29, at 381.

183. While quotas created for untouchables often look impressive, only a fraction of the available spaces are usually filled. The pattern is that the more prestigious the government job, the less the quotas are likely to be filled. While many administrators will claim that the quotas are not filled due to the lack of qualified untouchable candidates, often capable untouchable candidates face great prejudice. See Galanter, supra note 2, at 90-92, 97.

184. Professor Gadbois complains about the lack of awareness the United States has shown towards India's affirmative action system:

While Indian judges poll other jurisdictions to seek guidance in constitutional interpretation, American judges and lawyers do not. Despite India's by then 28 years of constitutional and judicial experience with affirmative action policies and litigation, not one of the 58 amicus briefs filed by more than 100 organizations in the Bakke case, as far as I am aware, made any 
serve as a simulation study for the United States. The United States will increasingly become a more culturally diverse society as the minority population continues to grow at a much faster rate than the Anglo population. ${ }^{185}$ If the economy continues to decline, competition for entry into positions in employment and education will most likely become keener. Under such conditions, the controversy over affirmative action is likely to intensify. A recent study conducted by the National Research Council of the National Academy of Sciences predicts that a worsening economy could result in greater racial tensions, which could lead to race riots and other forms of violent behavior reminiscent of the 1960's. ${ }^{186}$ The conditions just described are reflective of India today where, compared to the United States, there is far more cultural diversity and the competition for positions in employment and education is far more intense. In India, the controversy over affirmative action has been at the root of heightening controversy and social tension and has resulted in caste riots and other forms of violent protest. ${ }^{187}$ India's experience with affirmative action can serve as a guide to the United States in shaping its affirmative action policies in order to better prepare for the future.

One example of where the United States might benefit from studying Indian approaches to civil rights is in the area of language-related discrimination. Newly emerging areas in American constitutional law present problems involving English-only laws, treatment of bilingual skills in the workplace, ${ }^{188}$ and various other forms of linguistic based

mention of this Indian experience, and neither did the several judges who wrote opinions in that decision. Perhaps there was nothing in the Indian experience that could be usefully referred to by American judges and lawyers in 1977-1978, but it is unlikely that the Indian experience was even sampled. Gadbois, supra note 26, at 362 .

185. U.S. Department of Commerce, Statistical Abstract 14-15 (1991).

186. See Ariz. Daily Star, Jul. 28, 1989, $\&$ A, at 20.

187. See supre note 169.

188. One example of where the United States might benefit from studying Indian approaches to civil rights is in the area of bilingualism. A newly emerging area in American constitutional law presents the issue of whether bilingual skills should be recognized in the employment setting. Tim Golden, Workers Claim Extra Language Merits Extra Pay, N.Y. Times, 1990, reprinted in Ariz. Dally Star, May 20, 1990, at 1 and 4, col. B. A number of lawsuits have recently been filed in the U.S. courts by Hispanic litigants who claim that their special language skills warrant higher pay. Id. These litigants claim that their bilingual skills, instead of bringing them greater benefits, often lead to negative consequences. Such allegations have been made with increasing frequency in law enforcement agencies where Spanish speaking ability is often required. Id. 
discrimination. ${ }^{189}$ Professor Tribe predicts that multilingual ability in the employment setting "is going to be the new frontier of equal protection and anti-discrimination legislation and litigation." 190

The framers of the Indian Constitution took into consideration the problem of linguistic discrimination. ${ }^{191}$ India's ability to accommodate linguistic diversity, regardless of whether the language involved is indigenous or foreign, ${ }^{192}$ may hold solutions to the growing linguistic diversity in the United States.

The myriad of languages and dialects provide India with the reputation of being the most linguistically diverse and complex nation on earth. Accommodating linguistic diversity is vital for maintaining a unified India. Interestingly, beneficiaries of preferential treatment in Indian states have included members of various linguistic communities. ${ }^{193}$ Individual Indian states, with varying magnitudes of language related tensions, have adopted separate approaches to their linguistic problems. ${ }^{194}$

India provides a plethora of examples of successful and unsuccessful approaches in dealing with linguistic problems in employment, education, and life in general. While the controversies over multilingualism in the United States are relatively minor, they are bound to grow. The advent of English-only laws, for example, in a number of American states have already created resentment among Hispanics and other ethnic groups. ${ }^{195}$

189. The EEOC recently filed a suit in the U.S. District Court in Los Angeles which charged that the civil rights of an Indian-born employee were violated when he was fired from a company due to his East Indian accent. The Defendant-employer alleges that the dismissal was warranted since the Plaintiff's accent was a liability to the company's image. The EEOC alleges that the dismissal of an employee based on his or her accent violates the Title VII prohibition of discrimination based on national origin. See Steven Holmes, A discrimination first-U.S. sues company for firing man with foreign accent, N.Y. Times, 1992, reprinted in ARIz. DaILy STAR, January 18, 1992, at 6, col. A. Officials from the EEOC state that such suits concerning accent-based discrimination will increase due to the growing immigrant population. Id.

190. Golden, supra note 188.

191. See India Const. art. 29(2) (prohibits discrimination based on language in the admissions process in state-run educational institutions).

192. InDIA Const. art. 343 includes both Hindi, the official language of the India, and English as the major languages to be used for official purposes. Articles 345 and 347 allow states to adopt their own official language or languages.

193. Weiner \& Katzenstein, supra note 11, at 14-16.

194. See id. at 7-20.

195. While the controversies over multilingualism in the United States are relatively minor compared to India, they are bound to grow. The advent of English- 
India's approach to solving its linguistic crisis is only one example of where the United States may discover plausible approaches to its own newly emerging language related problems. The social reaction over affirmative action in India should be of particular interest to the United States. Has preferential treatment led to the perpetuation of caste and race? Critics in both countries claim that it has. Should the United States adopt an OBC-like category which would be intended to benefit other minorities who have also been the victims of discrimination, such as Jews and poor whites? Or would expanding preferential treatment lead to a deterioration in competitive values and individual merit which are so highly prized in American society? These are some of the general areas in which the United States and India could share their experiences.

The controversy over the fairness of preferential policies is a hot issue in both India and the United States. Some suggest that alternative policies in place of preferential treatment may be more suitable. ${ }^{196}$ For example, a direct approach would entail spending more funds on increasing educational opportunities and services for untouchables in India or blacks in the United States. ${ }^{197}$ While in theory this suggestion sounds attractive, the solution fails to take into consideration that sufficient funding may not be available for providing untouchables or blacks with better opportunities. Whatever alternatives may be presented for helping untouchables and blacks, there must always be a diversion of resources for the benefit of less privileged groups. Which segment of society will pay the costs of social welfare for the less privileged? The social per-

only laws in a number of American states have already created resentment among Hispanics and a number of other ethnic groups. One important issue raised by advocates of English-only laws is whether recognition of multiple languages leads to increased communalism and national disunity. While India has desperately attempted to obtain a consensus on one major language, such efforts have consistently failed. M.J. AKBaR, India: The Siege Within 86-94 (1985). In viewing India's linguistic tensions, a number of arguments for and against maintaining a monolingual United States are presented. One important issue raised by English-only law is the effect such a law would have on our democratic structure. Concerning the establishment of Hindi as India's national language, Prime Minister Nehru once stated "[i]t is not helpful to the development of Hindi if you force down any language upon a people or a group who resist that. Certainly in the democratic context of India it is an impossibility." Id. at 93 . In the context of American democracy, whether the English-only controversy will provide a new battleground for civil rights advocates is yet to be seen.

196. Weiner and Katzenstein mention a number of alternatives that governments have implemented in attempting to help the less privileged. Weiner \& Katzenstein, supra note 11 , at 138-39.

197. Id. 
ception over greater spending for untouchables may, in reality, be no different than the negative reaction that affirmative action has received in the United States. The solution to providing opportunities to such traditionally oppressed groups as blacks and untouchables may lie in whether society is willing and capable of spending resources to help alleviate a deeply rooted cultural ill. The answer to this question will have great implications for social stability in both India and the United States. In the meantime, the forces for social instability are increasing in both India and the United States.

In India, the downfall of V.P. Singh's government in 1990 which was due in part to the anger among higher caste voters over his strong support for the Scheduled Caste and other Indian minorities, ${ }^{198}$ and the corresponding rise of the BJP, ${ }^{199}$ the Hindu fundamentalist party, does not bode well for solving India's communal crisis. The religious campaigns launched by the $\mathrm{BJP}^{200}$ pose a threat to the fragile nature of India's secularism. The recent massacres of untouchables in Northern India over disputes concerning agrarian reform also highlight the continued oppression of untouchables by higher caste communities.

In the United States, the rise of white supremacist groups, such as the skinheads and the Ku Klux Klan, presents a direct threat to all minorities in the United States, such as blacks and Jews. The incidence of racial violence and hate crimes is on the rise. The increasing popularity of far right candidates, such as David Duke and his milder version, Pat Buchanan, also demonstrates the growing frustration the "majority" is feeling with the perceived advantages that minorities are reaping. In reality, blacks and Hispanics in the United States continue to occupy the bottom of the socio-economic ladder and many live in conditions resembling the third world.

Future interaction between India and the United States concerning affirmative action and the general problems concerning communal relations may never take place. This, however, will not prevent scholars from observing the similarities in cultural and legal trends between the two countries. In both India and the United States, laws protecting blacks and untouchables which are rooted within the constitution are being challenged by recent economic and cultural trends. The methods by which these law are strengthened, maintained, or weakened will

198. See Richard Sisson \& Munira Majmundar, India in 1990: Political Polarization, 31 Asian Survey, No.2, 103, Feb. (1991).

199. See id.

200. See id. 
reveal important information about the democratic systems in both countries.

\section{Conclusion}

The United States and India are two countries which have implemented affirmative action programs. The controversy over the justifications and success of affirmative action will continue well into the future. While some will argue that affirmative action in United States and India has led to worse race or caste relations, the implementation of such preferential programs indicate a willingness on the part of both countries to address the problem of discrimination. Those governments which have been slow to confront problems of discrimination within their own countries are now suffering the consequences of such neglect. The former Soviet Union is a prime example of where suppressed and ignored minorities did not waste time in establishing their separate homelands when they got the opportunity to express their free will.

In discussing the experiences of Indian untouchables and American blacks with affirmative action, there are many areas of comparison which warrant greater study and analysis. This analysis has been general and should be viewed as heuristic rather than one which provides specific remedies to complex problems. Also, scholars engaged in comparative and international studies on the legal aspects of discrimination may find some useful ideas from this discussion.

If a legal issue such as affirmative action can be compared between two such diverse cultures as the United States and India, then the scope for comparison between other countries should also increase. Many scholars have been reluctant to make comparisons between the United States and India due to perceived cultural irreconcilability. This perception may not only discourage scholars from making legitimate comparisons, but may also inhibit the motivation for borrowing innovative and effective ideas from other cultures due to their foreignness. 
